\title{
Análise vocal perceptivo-auditiva e acústica, falada e cantada de regentes de coral ${ }^{* * *}$
}

\author{
Perceptual, auditory and acoustic vocal analysis of speech and \\ singing in choir conductors
}

\author{
Maria Inês Beltrati Cornacchioni Rehder* \\ Mara Behlau**
}

*Fonoaudióloga. Doutora em Distúrbios da Comunicação Humana pela Universidade Federal de São Paulo - Escola Paulista de Medicina. Coordenadora da Área de PósGraduação em Voz - Cefac Saúde e Educação. Endereço para correspondência: Av 15, número 531 Centro - Rio Claro - SP - CEP 13500330 (mariainesrehder@uol.com.br).

**Fonoaudióloga. Doutora em Distúrbios da Comunicação Humana pela Universidade Federal de São Paulo - Escola Paulista de Medicina. Professora Orientadora do Programa de Pós-Graduação em Distúrbios da Comunicação Humana do Departamento de Fonoaudiologia da Universidade Federal de São Paulo - Escola Paulista de Medicina.

***Trabalho Realizado na Universidade Federal de São Paulo Escola Paulista de Medicina.

Artigo Original de Pesquisa

Artigo Submetido a Avaliação por Pares

Conflito de Interesse: não

Recebido em 28.03.2007.

Revisado em 06.06.2008; 24.07.2008. Aceito para Publicação em 28.07.2008.

\begin{abstract}
Background: the voice of choir conductors. Aim: to evaluate the vocal quality of choir conductors based on the production of a sustained vowel during singing and when speaking in order to observe auditory and acoustic differences. Method: participants of this study were 100 choir conductors, with an equal distribution between genders. Participants were asked to produce the sustained vowel "é" using a singing and speaking voice. Speech samples were analyzed based on auditory-perceptive and acoustic parameters. The auditoryperceptive analysis was carried out by two speech-language pathologist, specialists in this field of knowledge. The acoustic analysis was carried out with the support of the computer software Doctor Speech (Tiger Electronics, SRD, USA, version 4.0), using the Real Analysis module. Results: the auditory-perceptive analysis of the vocal quality indicated that most conductors have adapted voices, presenting more alterations in their speaking voice. The acoustic analysis indicated different values between genders and between the different production modalities. The fundamental frequency was higher in the singing voice, as well as the values for the first formant; the second formant presented lower values in the singing voice, with statistically significant results only for women. Conclusion: the voice of choir conductors is adapted, presenting fewer deviations in the singing voice when compared to the speaking voice. Productions differ based the voice modality, singing or speaking.
\end{abstract}

Key Words: Voice; Acoustics; Auditory Perception; Voice Quality.

\section{Resumo}

Tema: voz de regentes de coral. Objetivo: avaliar a qualidade vocal de regentes de corais, nas emissões de uma vogal sustentada, nas modalidades de voz falada e cantada, para observar diferenças auditivas e acústicas. Método: participaram como sujeitos 100 regentes de coral, em igual número de ambos os sexos, solicitados a emitir a vogal "é" sustentada, nas modalidades de voz falada e cantada. O material de fala foi analisado do ponto de vista perceptivo auditivo e acústico. A análise perceptivo-auditiva foi realizada por dois fonoaudiólogos especialistas em voz. A análise acústica foi realizada com o auxílio do programa computadorizado Doutor Speech (Tiger Eletronics, SRD, EUA, versão 4.0), com a utilização do módulo Real Analysis. Resultados: a análise perceptivo-auditiva da qualidade vocal indicou que a maioria dos regentes possui vozes adaptadas, com maiores alterações na modalidade da voz falada. A análise acústica indicou valores diferentes para os sexos e para as modalidades de emissão. A freqüência fundamental foi mais elevada na voz cantada, assim como os valores do primeiro formante; o segundo formante apresentou valores mais reduzidos para a voz cantada, com significância estatística apenas para as mulheres. Conclusão: as vozes dos regentes de coral são adaptadas, com menor desvio na voz cantada quando comparada com a falada. As emissões são diferenciadas de acordo com a modalidade, voz falada ou cantada.

Palavras-Chave: Voz; Acústica; Percepção Auditiva; Qualidade da Voz. 


\section{Introduction}

The choir conductor is a professional with the particular characteristic of using at the same time the spoken and sung voice. The spoken voice is used to convey instructions and orders, describe purposes, explain stile characteristics, work on text pronunciation aspects and on linguistic nuances and to control the group's discipline. The sung voice is used to provide examples of different voice characteristics to the choir members of different voice classifications, to correct voice projection and tune, besides frequently presenting examples of the several kinds of emission $(1,2)$. This professional also participates of other choirs and has other lateral teaching activities (3).

To the speech and language pathologist studying the choir conductor's voice is fundamental to understand the vocal mechanisms that are specific and particular to the use of spoken and sung voices. The speech and language pathologists practice with choirs, conductors and choir singers may become more specific with the contribution of this study, especially in what refers to prevention and orientation.

The purpose of the present study was to evaluate the vocal quality of choir conductors during the emission of a sustained vowel on the modalities of spoken and sung voices to observe auditory and acoustic differences.

\section{Method}

This paper is part of a research approved by the ethics research commission of the institution. All subjects signed the consent form according to the resolution 196/96 of the National Research Ethics Commission (CONEP).
Participated in this study 100 subjects, 50 females and 50 males with ages varying from 20 to 65 years, all conductors of children, juvenile or adult choirs of the state of Sao Paulo. To characterize the conductors a questionnaire exploring different aspects of professional formation and activity and vocal data was used (4).

To the auditory perceptual analysis of vocal quality and the computerized acoustic analysis of the vocal sign each conductor provided two vocal samples of sustained emission of the vowel "é" on the modalities of spoken and sung voice. Two speech and language pathologists, voice specialists, performed the auditory perceptual analysis classifying the emissions as adapted or altered (5) and according to the GIRBAS analysis scale (6). The acoustic analysis of the mean, maximal and minimal fundamental frequencies, and of the values of the first three formants were performed with the use of the Dr Speech program (TIGER ELATRONICS SRD, EUA, version 4.0). The values of the formants were manually read considering the mean values of the harmonic increment peaks through the linear predicting code (LPC).

The t-Student test to parametric variables was used and the proportions with p-value under 0.05 (5\%) were considered statistically significant. To the evaluation of the relations between pairs of variables the Spearman correlation analysis was used. The statistically significant values are marked. 


\section{Results}

TABLE 1. Numeric and proportional distribution of the auditory perceptual analysis of vocal quality and deviations found on the GIRBAS scale parameters of spoken and sung voices of choir conductors of both genders.

\begin{tabular}{|c|c|c|c|c|c|c|}
\hline & & Spo & & & & Significance \\
\hline & & $\mathrm{N}$ & $\%$ & $\mathrm{~N}$ & $\%$ & $(\mathrm{p})$ \\
\hline Male & & & & & & \\
\hline & Adapted & 36 & 72 & 41 & 82 & 0.317 \\
\hline Auditory perceptual & Altered & 14 & 28 & 9 & 18 & 0.239 \\
\hline & Total & 50 & 100 & 50 & 100 & \\
\hline & 0 & 37 & 74 & 41 & 82 & 0.667 \\
\hline Global Deoree & 1 & 13 & 26 & 9 & 18 & 0.667 \\
\hline Global Degree & 2 & 0 & 0 & 0 & 0 & 1.000 \\
\hline & 3 & 0 & 0 & 0 & 0 & 1.000 \\
\hline & 0 & 50 & 100 & 50 & 100 & 1.000 \\
\hline & 1 & 0 & 0 & 0 & 0 & 1.000 \\
\hline Instability & 2 & 0 & 0 & 0 & 0 & 1.000 \\
\hline & 3 & 0 & 0 & 0 & 0 & 1.000 \\
\hline & 0 & 39 & 78 & 43 & 86 & 0.699 \\
\hline Hoarcenecs & 1 & 11 & 22 & 7 & 14 & 1.000 \\
\hline Hoarseness & 2 & 0 & 0 & 0 & 0 & 0.562 \\
\hline & 3 & 0 & 0 & 0 & 0 & 1.000 \\
\hline & 0 & 46 & 92 & 47 & 94 & 0.644 \\
\hline Breathinesc & 1 & 4 & 8 & 3 & 6 & 0.414 \\
\hline Breatniness & 2 & 0 & 0 & 0 & 0 & 0.562 \\
\hline & 3 & 0 & 0 & 0 & 0 & 1.000 \\
\hline & 0 & 50 & 100 & 50 & 100 & 1.000 \\
\hline Asthenig & 1 & 0 & 0 & 0 & 0 & 1.000 \\
\hline Asthenıa & 2 & 0 & 0 & 0 & 0 & 1.000 \\
\hline & 3 & 0 & 0 & 0 & 0 & 1.000 \\
\hline & 0 & 50 & 100 & 49 & 98 & 1.000 \\
\hline Tencion & 1 & 0 & 0 & 1 & 2 & 1.000 \\
\hline Iension & 2 & 0 & 0 & 0 & 0 & 1.000 \\
\hline & 3 & 0 & 0 & 0 & 0 & 1.000 \\
\hline Female & & & & & & \\
\hline & Adapted & 32 & 64 & 38 & 76 & 0.480 \\
\hline Auditory perceptual & Altered & 18 & 36 & 12 & 24 & 0.194 \\
\hline & Total & 50 & 100 & 50 & 100 & \\
\hline & 0 & 34 & 68 & 36 & 72 & 0.339 \\
\hline Glohal Deoree & 1 & 16 & 32 & 14 & 28 & 0.339 \\
\hline Gilobal Degree & 2 & 0 & 0 & 0 & 0 & 1.000 \\
\hline & 3 & 0 & 0 & 0 & 0 & 1.000 \\
\hline & 0 & 50 & 100 & 50 & 100 & 1.000 \\
\hline Inctohility & 1 & 0 & 0 & 0 & 0 & 1.000 \\
\hline Instability & 2 & 0 & 0 & 0 & 0 & 1.000 \\
\hline & 3 & 0 & 0 & 0 & 0 & 1.000 \\
\hline & 0 & 47 & 94 & 47 & 94 & 0.303 \\
\hline & 1 & 3 & 6 & 3 & 6 & 0.303 \\
\hline Hoarseness & 2 & 1 & 2 & 0 & 0 & 1.000 \\
\hline & 3 & 0 & 0 & 0 & 0 & 1.000 \\
\hline & 0 & 36 & 72 & 39 & 78 & 0.699 \\
\hline Breathiness & 1 & 13 & 26 & 11 & 22 & 0.699 \\
\hline Breathıness & 2 & 1 & 2 & 0 & 0 & 1.000 \\
\hline & 3 & 0 & 0 & 0 & 0 & 1.000 \\
\hline & 0 & 50 & 100 & 50 & 100 & 1.000 \\
\hline & 1 & 0 & 0 & 0 & 0 & 1.000 \\
\hline Asthenıa & 2 & 0 & 0 & 0 & 0 & 1.000 \\
\hline & 3 & 0 & 0 & 0 & 0 & 1.000 \\
\hline & 0 & 49 & 98 & 49 & 98 & 0.320 \\
\hline & 1 & 1 & 2 & 1 & 2 & 0.320 \\
\hline Tension & 2 & 0 & 0 & 0 & 0 & 1.000 \\
\hline & 3 & 0 & 0 & 0 & 0 & 1.000 \\
\hline
\end{tabular}


TABLE 2. Mean values and standard deviation of the mean, maximal and minimal frequencies and of the frequency formants of the emission of sustained vocal on the modalities of spoken and sung voices according to gender $(\mathrm{N}=100)$.

\begin{tabular}{|c|c|c|c|c|c|c|}
\hline & & \multicolumn{2}{|c|}{ Spoken voice } & \multicolumn{2}{|c|}{ Sung voice } & \multirow{2}{*}{$\begin{array}{c}\text { Significance } \\
\text { (p) }\end{array}$} \\
\hline & & Mean & SD & Mean & SD & \\
\hline \multicolumn{7}{|l|}{ Male } \\
\hline & Mean frequency & 135.43 & 26.10 & 176.81 & 41.68 & $0.001 *$ \\
\hline & Maximal frequency & 137.58 & 26.45 & 179.57 & 41.91 & $0.001 *$ \\
\hline & Minimal frequency & 132.69 & 25.99 & 174.09 & 41.37 & $0.001 *$ \\
\hline & $\mathrm{F}_{1}$ & 515.63 & 54.71 & 558.84 & 57.29 & $0.001 *$ \\
\hline & $\mathrm{F}_{2}$ & 1739.38 & 163.94 & 1688.32 & 261.32 & 0.198 \\
\hline & $\mathrm{F}_{3}$ & 2644.00 & 382.25 & 2703.56 & 405.78 & 0.188 \\
\hline \multicolumn{7}{|l|}{ Female } \\
\hline & Mean frequency & 229.09 & 27.23 & 338.48 & 95.44 & $0.001 *$ \\
\hline & Maximal frequency & 232.36 & 27.92 & 342.95 & 96.98 & $0.001 *$ \\
\hline & Minimal frequency & 225.13 & 26.99 & 330.74 & 93.55 & $0.001 *$ \\
\hline & $\mathrm{F}_{1}$ & 629.06 & 77.92 & 672.12 & 100.40 & $0.007 *$ \\
\hline & $\mathrm{F}_{2}$ & 2001.31 & 208.26 & 1902.57 & 161.61 & $0.002^{*}$ \\
\hline & $\mathrm{F}_{3}$ & 2935.01 & 345.32 & 2881.75 & 242.46 & 0.270 \\
\hline
\end{tabular}

TABLE 3. Pair correlation analysis of the auditory perceptual and acoustic parameters on spoken and sung emissions of choir conductors according to gender and with significance below $5 \%$.

\begin{tabular}{|c|c|c|}
\hline Pair of variables & correlation sign & Significance value $(p)$ \\
\hline \multicolumn{3}{|l|}{ Male } \\
\hline \multicolumn{3}{|l|}{ Spoken fundamental frequency } \\
\hline $\mathrm{F}_{0}$ of spoken voice $\mathrm{x} \mathrm{F}_{0}$ of sung voice & + & $0.001 *$ \\
\hline $\mathrm{F}_{0}$ of spoken voice $\mathrm{x}$ years of singing classes & + & $0.028 *$ \\
\hline \multicolumn{3}{|l|}{ Sung fundamental frequency } \\
\hline $\mathrm{F}_{0}$ of sung voice $\mathrm{x}$ voice perceived as sang & + & $0.046^{*}$ \\
\hline \multicolumn{3}{|l|}{ Formant } \\
\hline $\mathrm{F}_{2}$ of spoken voice $\mathrm{x} \mathrm{F}_{3}$ of spoken voice & + & $0.021 *$ \\
\hline$F_{2}$ of spoken voice $\times F_{2}$ of sung voice & + & $0.001 *$ \\
\hline $\mathrm{F}_{2}$ of spoken voice $\mathrm{x} \mathrm{F}_{3}$ of sung voice & + & $0.049 *$ \\
\hline$F_{3}$ of spoken voice $\times F_{3}$ of sung voice & + & $0.001 *$ \\
\hline$F_{1}$ of sung voice $x F_{3}$ of spoken voice & - & $0.035^{*}$ \\
\hline$F_{1}$ of sung voice $x$ voice perceived as sung & + & $0.046^{*}$ \\
\hline$F_{2}$ of sung voice $x F_{3}$ of sung voice & + & $0.001 *$ \\
\hline \multicolumn{3}{|l|}{ Female } \\
\hline \multicolumn{3}{|l|}{ Spoken fundamental frequency } \\
\hline $\mathrm{F}_{0}$ of spoken voice $\mathrm{x} \mathrm{F}_{1}$ of spoken voice & + & $0.001 *$ \\
\hline $\mathrm{F}_{0}$ of spoken voice $\mathrm{x}$ of sung voice & + & $0.013^{*}$ \\
\hline \multicolumn{3}{|l|}{ Formant } \\
\hline$F_{1}$ of spoken voice $\times F_{1}$ of sung voice & + & $0.039 *$ \\
\hline $\mathrm{F}_{2}$ of spoken voice $\times \mathrm{F}_{3}$ of spoken voice & + & $0.001 *$ \\
\hline $\mathrm{F}_{2}$ of spoken voice $\mathrm{x} \mathrm{F}_{2}$ of sung voice & + & $0.002 *$ \\
\hline$F_{2}$ of spoken voice $\mathrm{x} \mathrm{F}_{3}$ of sung voice & + & $0.047 *$ \\
\hline$F_{2}$ of spoken voice $\mathrm{x}$ voice perceived as sung & - & $0.037 *$ \\
\hline$F_{3}$ of spoken voice $x F_{3}$ of sung voice & + & $0.001 *$ \\
\hline $\mathrm{F}_{3}$ of spoken voice $\mathrm{x}$ voice perceived as spoken & - & $0.036^{*}$ \\
\hline$F_{2}$ of sung voice $x F_{3}$ of sung voice & + & $0.007 *$ \\
\hline $\mathrm{F}_{2}$ of sung voice $\mathrm{x}$ years of singing classes & - & $0.026^{*}$ \\
\hline
\end{tabular}




\section{Discussion}

Most of the conductors presented adapted spoken and sung emissions with higher disorder indexes on the spoken voice suggesting a vocal production compatible with the professional development and healthier motor adjusts on sung voice (7-11). The identification of zero degree of vocal disorder on GIRBAS scale and the higher indexes on global degree on spoken voice confirm that adaptation (12). Data about hoarseness may suggest lack of vocal conditioning and/or ignorance about basic rules of vocal hygiene to speech and singing (12-19). The higher breathiness of the female subjects confirms the larger tendency of glottic clefts on women due to the female larynx anatomical pattern (20). The habit of projected voice emission and the focus on pedagogical training agree with the absence of asthenia and the discrete tension index $(1-2,9,12)$.

The increase of the fundamental frequency of the sustained vowel was decisive to the identification of the sung voice $(8,21,22)$ suggesting different mechanisms of voicing and articulation on the differentiation of modalities $(3,12,23,24)$.

The choir conductors discriminate spoken from sung emissions through the first formant using specific articulation adjusts during sung voice training: larger jaw opening, larger pharyngeal constriction, greater lowering of the tongue's anterior portion, smaller degree of lips rounding and smaller degree of oral-pharyngeal elongation. The mechanisms used by the female regents to the differentiation of the two first formants were a larger degree of jaw opening and a larger degree of

\section{References}

1. Zander O. Regência coral. 5. ed. Porto Alegre: Movimento; 2003. 89p.

2. Ginsborg J. Shared performance cues in singing and conducting: a content analysis of talk during practice. Psychology of Music. 2006;2:167-94.

3. Fernades AJ, Kayama AG, Östergren EA. A prática coral na atualidade: sonoridade, interpretação e técnica vocal. Musica Hodie. 2006;1:51-74.

4. Rehder MI. Perfil vocal de regentes de corais do estado de São Paulo. 1999. 68f. Tese (Mestrado). Universidade Federal de São Paulo, São Paulo.

5. Behlau M, Azevedo R, Pontes, P. Conceito de voz normal e classificação das disfonias. In: Behlau M Voz o livro do especialista I. São Paulo: Revinter; 2001. p. 53-79. pharyngeal constriction to the differentiation of F1 and the posteriorization and elevation of the tongue's posterior portion to the differentiation of F2 (24-28).

The parallel correlation on Spearman's analysis indicates an intrinsic articulation dependence between the second and third formants. The position of the point of the tongue behind the incisive teeth with its posterior portion constricted against the palatal velum reduces the values of F2 e F3. The opposite is also true: the lips elongation degree and the vocal tract shortening are also pointed as related to the parallel increase or decrease of F2 e F3 values $(25,27)$.

\section{Conclusions}

Based on the auditory and acoustic analysis of the voice quality of choir conductors during the emission of a sustained vowel on the modalities of spoken and sung voice, it can be concluded that:

1. Most of the choir conductors have adapted spoken and sung voices, with discrete deviations of the global degree of dysphonia and spoken emissions with more disorders.

2. Conductors of both genders differentiate adapted spoken voice and sung voice through the fundamental frequency and the first formant. The female conductors differentiate spoken voice from sung voice also through the second formant.

3. Conductors of both genders presented parallel relations between the second formant of the spoken voice and the second and third formants of sung voice and between the third formant of the spoken voice and the third formant of the sung voice.

6. Dejonckere P, Remacle M, Freznel-Elbaz E. Reability and relevance of differentiated perceptual evaluation of pathological voice quality. In: Clemente MP Voice update. Amsterdam: Elsevier; 1966. p. 321-4.

7. Mendes AP, Rothman HB; Sapienza C, Brown WS. Effects of vocal training on the acoustic parameters of singing voice. J Voice. 2003;17:529-43.

8. Estienne F. Voz falada, voz cantada. Rio de Janeiro: Revinter; 2004. 64p.

9. Silva MA, Duprat AC. Voz cantada. In: Ferreira LP, BefiLopes DM, Limongi SCO. Tratado de fonoaudiologia. São Paulo: Rocca; 2004. p. 177-94.

10. Behlau MS, Feijó D, Madazio G, Rehder MI, Azevedo R, Ferreira AE. Voz profissional: aspectos gerais e atuação fonoaudiológica. In: Behlau M. Voz: o livro do especialista II. Rio de Janeiro: Revinter; 2005. p. 287-406. 
11. Andrade SR, Cielo CA. A ciência fonoaudiológica e a arte do canto coral. Fono Atual. 2005;8:59-68.

12. Behlau M, Rehder MI. Higiene vocal para o canto coral. São Paulo: Revinter, 1997. 44p.

13. Vasilenko L, Pavlikhin OG, Izgarysheva ZA. Analysis of the causes of vocal tract diseases in singers. Vestn Otorinolaringol. 2000;5:13-7.

14. Sataloff RT. Professional voice users: the evaluation of voice disorders. Occup Med. 2001;4:633-47.

15. Timmermans B, De Bodt MS, Wuyts FL, Boudewijns A, Clement G, Peeters A, Van de Heyning PH. Poor voice quality in future elite vocal performers and professional voice users. J Voice. 2002;3:372-82.

16. Solomon NP, Glaze LE, Arnold RR, Van Mersbergen M. Effects of a vocally fatiguing task and systemic hydration on men's voices. J Voice. 2003;1:31-46.

17. Welham NV, Maclagan MA. Vocal fatigue: current knowledge and future directions. J Voice. 2003;17:21-30.

18. Ribeiro L, Hanayama EM. Perfil vocal de coralistas amadores. Rev CEFAC. 2005;7:252-66.

19. Timmermans B, Vanderwegen J, De Bodt MS. Outcome of vocal hygiene in singers. Curr Opin Otolaryngol Head Neck Surg. 2005;3:138-42.

20. Behlau M, Azevedo R, Pontes P, Brasil, O. Disfonias Funcionais. In: Behlau M Voz o livro do especialista I. São Paulo: Revinter; 2001. p. 85-245.
21. Rothamn HB, Brown WS, Sapienza CM, Morris RJ. Acoustic analyses of trained singers perceptualy identified from speaking samples. J. Voice. 2001;15:25-35.

22. Pillot $\mathrm{C}$, Vaissière $\mathrm{J}$. Vocal effectiveness in speech and singing: acoustical, physiological and perceptive aspects. Applications in speech therapy. Rev Laryngol Otol Rhinol (Bord). 2006;5:293-8.

23. Cleveland TF, Sundberg J, ED Stone R. Long-termaverage spectrum characteristics od country singers during speaking and singing. J. Voice. 2001;15:54-60.

24. Titze IR. A theoretical study of F0-F1 interaction with application to resonant speaking and singing voice. J Voice. 2004;18:292-8.

25. Adrianopoulos MV, Darrow K, Chen J. Multimodal standartization of voice among four multicultural populations formant structures. J. Voice. 2001;15:61-77.

26. Erickson ML, D'Alfonso AE. A comparison of two methods of formant frequency estimation for high-pitched voices. J Voice. 2002;16:147-71.

27. Sundberg J. Research on the singing voice in restrospect. Speech, music and hearing department at the royal institute of technology. Stockholm, Sweden. 2003;45:11-22.

28. Vurma A, ROSS J. The perception of "forward" and "backward placement" of the singing voice. Logoped Phoniatr Vocol. 2003;28:19-28. 